Jaqueline Evaristo Arimatea ${ }^{1}$

Cosme Marcelo Furtado Passos da Silva ${ }^{2}$

Antonio José Leal Costa ${ }^{1}$

Sandra Costa Fonseca ${ }^{3}$

Silvana Granado Nogueira Gama ${ }^{2}$

Elisa Maria de Aquino Lacerda ${ }^{4}$

Pauline Lorena Kale ${ }^{1}$

\title{
Low birthweight and postnatal weight in full-term infants under six months old, Rio de Janeiro, RJ, Brazil
}

\author{
Baixo peso ao nascer e peso pós-natal em bebês a termo \\ menores de seis meses de idade, Rio de Janeiro, RJ, Brasil
}

${ }^{1}$ Departamento de Medicina Preventiva, Faculdade de Medicina e Instituto de Estudos em Saúde Coletiva, Universidade Federal do Rio de Janeiro. Av. Horácio Macedo $s / \mathrm{n}^{\circ}$, Cidade Universitária. 21941-598 Rio de Janeiro RJ Brasil. jaquearimatea@ yahoo.com.br ${ }^{2}$ Departamento de Epidemiologia e Métodos Quantitativos em Saúde Escola Nacional de Saúde Pública Sergio Arouca. ${ }^{3}$ Instituto de Saúde da Comunidade, Universidade Federal Fluminense. ${ }^{4}$ Instituto de Nutrição Josué de Castro, Universidade Federal do Rio de Janeiro.
Abstract This study investigated the association between low birthweight and postnatal weight in full-term infants, taking social, economic, maternal and babies characteristics into account. A cross-sectional study was conducted with infants under six months old at 27 primary healthcare units in the Rio de Janeiro municipality, Brazil, in 2007. Only singleton full-term babies were included. The association between full-term low birthweight and postnatal weight was tested using the multiple regression model adjusted for the gender and age of the baby, as well as potential confounding factors. A total of 875 babies were evaluated, of whom $4.5 \%$ were small for gestational age. Small-for-gestational-age babies weighted, on average, 977.4 grams less than those born with adequate weight for gestational age, after adjustment by gender and age, as well as marital status and parity. Girls were 426.74 grams lighter than boys; children from mothers with live-in partners were 146.2 grams heavier than those of single mothers, and the babies of primiparae weighed 204.67 grams less than the children of multiparae. Low birthweight is an unfavorable factor for postnatal weight of full-term infants. These children, particularly daughters of primipara single mothers, must be followed more frequently in relation to their postnatal growth.

Key words Infant, Low birth weight, Term birth, Weight gain
Resumo Este estudo investigou a associação entre baixo peso ao nascer e peso pós-natal em crianças a termo, considerando-se características sociais, econômicas, maternas e infantis. Estudo transversal realizado em bebês com até seis meses de idade em 27 unidades de Atenção Primária à Saúde. Foram incluídos no estudo somente bebês a termo e não gemelares. A associação entre baixo peso ao nascer e peso pós-natal em crianças a termo foi testada utilizando modelo de regressão múltipla ajustada por sexo e idade do bebêe potenciais confundidores. Foram avaliadas 875 crianças, das quais $4,5 \%$ eram de baixo peso ao nascer. O peso pós-natal dos bebês a termo e com baixo peso foi em média 977,4 gramas menor do que entre aqueles que nasceram a termo com peso adequado, depois de ajustado por sexo e idade da criança, situação conjugal e paridade. Meninas pesavam 426,74 gramas a menos do que meninos, filhos de mães com parceiros pesavam 146,2 gramas a mais do que sem parceiros e os bebês de primíparas pesavam 204,67 gramas a menos do que os de multiparas. Nascer com baixo peso é uma situação desfavorável para o peso pós-natal de bebês a termo. Essas crianças, particularmente filhas de mães sem parceiros e primiparas, devem ser acompanhadas mais frequentemente em relação ao crescimento pós-natal.

Palavras-chave Recém-nascido de baixo peso, Nascimento a Termo, Ganho de Peso 


\section{Introduction}

Birthweight by gestational age is an indirect indicator of fetal growth, quite widely used in clinical practice and Public Health ${ }^{1}$. The World Health Organization defines small for gestational age as babies whose birthweight falls below the tenth percentile expected for gender-specific birthweight by gestational age ${ }^{2}$. Another classification uses the cut-off point of two standard deviations below the expected mean for the gestational age ${ }^{3}$. Although not exactly representing the phenomenon of intrauterine growth restriction, which would require longitudinal measurements during pregnancy ${ }^{2}$, small for gestational age is more easily measured and has been used in several studies.

When information on gestational age is categorized in intervals, classification of babies as small for gestational age is hampered. In this situation, a simplified small for gestational age definition can be used, considering babies born full-term ( $>37$ weeks) but of a low birthweight $(<2,500 \mathrm{~g})^{4}$. These values coincide with small for gestational age cut-off classification for full-term babies on several growth curves, including that drawn up by Williams et al. ${ }^{5}$ recommended by the World Health Organization, and that of Alexander et al. ${ }^{6}$ and almost overlap the values of a Brazilian curve based on national data from 2003 to $2005^{7}$. However, the use of this simplified definition requires caution when interpreting the findings, as small for gestational age newborns with higher gestational ages could be underestimated. Since 2000, it is believed that there has been a reduction in the occurrence of intrauterine growth restriction in Brazil as, despite the increase in preterm births, low birthweight frequency has remained relatively stable ${ }^{8}$, with a significant increase in the frequency of preterm births among newborns weighing less than 2,500 grams .

Postnatal growth depends on genetic potential, intrauterine growth and the effects of a wide variety of socioeconomic, cultural, nutritional and environmental factors, as well as the occurrence of morbidities affecting weight and height ${ }^{10-12}$. It is important to follow the babies more frequently in relation to their postnatal growth speed as well as the catch-up and catchdown phenomena ${ }^{13}$. According to a review by Chrestani et al. ${ }^{13}$, there is no uniformity in the operational definition of accelerated growth, nor in the catch-up concept. Accelerated growth is associated with primiparity, smoking during pregnancy, low birthweight and early weaning.
Healthy full-term newborns, even if small for gestational age, tend to catch up during the first year of life ${ }^{14}$. In a birth cohort of full-term Brazilian babies, an initial accelerated growth was noted during the first six months of life that was more pronounced among low birthweight babies, although weight and length during the first year still remained lower than those of babies with adequate birthweight ${ }^{15}$.

The association between postnatal catch-up and chronic or degenerative diseases has been widely discussed in the literature on fetal programming $^{16,17}$. At the moment, there is no evidence that rapid gains in weight or length during the first two years of life increase the risk of chronic disease, even among babies with intrauterine growth restriction. The adequate nutrition in utero and also during the first 1000 days of live is essential for formation of human capital ${ }^{18}$.

In a recent meta-analysis of 19 longitudinal birth cohorts, including Brazilian children, small for gestational age was associated with a 2.4 times increased odds of childhood stunting in low and middle-income countries ${ }^{19}$. We investigated the association between low birthweight and postnatal weight, taking socioeconomic and maternal characteristics into consideration, as well as factors related to pregnancy, birth and the infants themselves, among full-term babies under six months old at primary healthcare clinics publicly funded by Brazil's Unified National Health System (SUS) in the Rio de Janeiro municipality in 2007.

\section{Method}

\section{Population and Study Design}

A cross-sectional study was conducted with 1,082 babies less than six months old at 27 primary healthcare units from Brazil's Unified National Health System (SUS), in the city of Rio de Janeiro between June and September, 2007.

The two-stage sampling consisted initially in selecting primary healthcare units from Brazil's Unified National Health System (SUS) and then, babies under six-month age. In order to ensure a geographic representative sample of the city, Euclidian distances from the geographic coordinates of the primary healthcare units to the Administrative Center of the city of Rio de Janeiro were calculated and then ranked. A systematic selection of the healthcare units was done considering the probability of selection proportional to the monthly average number of childcare appoint- 
ments of babies under six months in the first semester of 2005. At the second-stage of sampling, the babies were systematically selected soon after the childcare appointment. The total number of the survey sample, considering a bilateral error of $13 \%$ and a confidence level of $95 \%$, resulted in 27 healthcare units and 40 babies per unit (1.080 mother interviews ${ }^{20}$.

Data were obtained via interviews with the mothers and from pediatric healthcare records. All data collection was performed by trained healthcare practitioners. Due to incomplete information on gestational age, which was an eligibility criterion for this study, the database of the survey was linked to the Live Births Information System (SINASC) database, which provided information on mothers, their pregnancies and births for all Brazilian children.

To be included in this study, children had to be singleton full term births (gestational age $\geq$ 37 weeks). Babies were excluded when information on gestational age, birthweight or postnatal weight was not available.

This study was performed in agreement with the Declaration of Helsinki (1964) and approved by the local ethical committee at Federal University of Rio de Janeiro. Each participant was presented with a deed of informed consent before the interview, with voluntary signature.

\section{Variables}

The main outcome was the postnatal weight gain of the child in grams (dependent variable), based on the child weight reported by mother on the same day of the interview. The main predictor variable was birthweight less than 2,500 grams. As the study population is full-term babies, babies with low birthweight $(<2,500$ grams) are considered with intrauterine malnutrition ${ }^{4}$.

Other variables were maternal characteristics grouped by: 1) Demographic, social and economic factors: remunerated work (yes; no), years of schooling ( $<$ four years; four to seven years; $\geq$ eight years); marital status (with / without livein partner) and age $(<20 ; 20-34 ; \geq 35$ years old $)$ and 2) Reproductive and prenatal characteristics: parity (primipara; multipara) and prenatal care adequacy (inadequate; fair; adequate and more than adequate).

Prenatal care was assessed by the Kotelchuck Index, adapted to the number of appointments recommended in Brazil $^{21}$. For this analysis, the extreme categories were grouped together (in- adequate and fair, and adequate with more than adequate).

Child co-variables were: gender (male; female); age $(0$ to $<$ one month; one to $<$ two months; two to $<$ three months; three to $<$ four months; four to $<$ five months; five to $<$ six months), type of breast feeding (not applicable HIV+ mother for example - or not stated; exclusive breast feeding; predominant breast feeding; supplemented breast feeding; no longer breast feeds) ${ }^{22}$, day-care center (yes; no) and hospital admission history (yes; no).

The source of information on birthweight, gestational age, type of pregnancy and type of birth was the SINASC, while other information was obtained via interviews during the survey

\section{Statistical Analysis}

Proportions are presented for categorical variables and summary statistics for continuous variables. Birthweight (in grams) was analyzed on an exploratory basis as a continuous variable and as a categorical one $(<2,500$ grams; 2,500 to 3,999 grams; $\geq 4,000$ grams).

For preliminary analyses, it was investigated associations between the dependent variable, postnatal weight gain of the child in grams, and each co-variable ajusted by baby's age and gender, using multiple linear regression models. Variables presenting regression coefficients with a statistical significance level of less than 0.20 through the Student $t$ test were selected for the multivariable analysis. The comparison between models was based on the adjusted Wald F test. In the final multivariable model, we retained variables with regression coefficients less than 0.05 level. The modeling, linearity, homoscedasticity and normality assumptions were verified for each adjusted model.

The Statistical Package for the Social Sciences (SPSS) version 17.0 software was used.

\section{Results}

Of the 1,082 babies assessed by the survey, 1,021 (94.4\%) presented information on gestational age, with a $6.4 \%$ prevalence of preterm births. For this study, 952 babies met inclusion criteria not preterm and singleton - all with information on birthweight; but 77 had no information on postnatal weight and were excluded. The study population comprised 875 babies. 
Table 1 presents the characteristics of mothers. There was a high proportion of adolescents, only a small percent of mothers had low educational level and $61.1 \%$ had completed at least their basic education. The presence of a live-in partner was stated by $86.1 \%$ and $64.9 \%$ had no remunerated work. In terms of their reproductive history, $55 \%$ of the babies were the offspring of multipara mothers. Prenatal care was adequate or more than adequate in $60.1 \%$ of the cases.

Babies presented a slight predominance of males and were mainly between one and four months of age. The lowest percentages corresponded to the extreme ages (Table 2).

Full-term low birthweight prevalence was $4.5 \%$. Exclusive breast feeding and supplemented breast feeding predominated among the babies. Most of them did not go to day care centers and had never been hospitalized (Table 2).

The birthweight distribution curve follows a normal probability distribution with limited amplitude. The mean and standard deviation for birthweight were respectively 3,225.8 \pm 454.5 grams (Graphic 1).

Table 1. Maternal characteristics - full-term infants up to six months old ( $\mathrm{N}=875)$, Rio de Janeiro, RJ, Brazil, 2007.

\begin{tabular}{|c|c|}
\hline & $\begin{array}{r}\text { Participants } \\
\mathbf{n}(\%)\end{array}$ \\
\hline \multicolumn{2}{|c|}{ Demographic, social and economic characteristics } \\
\hline \multicolumn{2}{|c|}{ Age (years) } \\
\hline $10-19$ & $181(20.7)$ \\
\hline $20-34$ & $626(71.5)$ \\
\hline 35 or more & $68(7.8)$ \\
\hline \multicolumn{2}{|l|}{ Marital Status } \\
\hline With live-in partner & $753(86.1)$ \\
\hline Without live-in partner & $122(13.9)$ \\
\hline \multicolumn{2}{|l|}{ Remunerated work } \\
\hline Yes & $307(35.1)$ \\
\hline No & $568(64.9)$ \\
\hline \multicolumn{2}{|l|}{ Education (years of study) } \\
\hline$<4$ & $56(6.4)$ \\
\hline $4-7$ & $284(32.5)$ \\
\hline$\geq 8$ & $535(61.1)$ \\
\hline \multicolumn{2}{|l|}{ Reproductive history } \\
\hline \multicolumn{2}{|l|}{ Parity } \\
\hline Primipara & $394(45.0)$ \\
\hline Multipara & $481(55.0)$ \\
\hline \multicolumn{2}{|l|}{ Characteristics of Pregnancy and Birth } \\
\hline \multicolumn{2}{|l|}{ Adequacy to prenatal care } \\
\hline No/inadequate pre-natal care & $115(13.1)$ \\
\hline Fair & $229(26.2)$ \\
\hline Adequate or more than adequate & $526(60.1)$ \\
\hline Unknown & $5(0.6)$ \\
\hline
\end{tabular}

In the preliminary analysis, variables associated (statistical significance level <0.20) with postnatal weight, after adjustement for child's age and gender were: small for gestational age, marital status and parity.

The best model tested in the multiple linear regression analysis for explaining postnatal weight $(\mathrm{P}$ value $<0.0001)$ retained the same explanatory variables with a statistical significance level of 0.05 , also adjusted for age and gender (Table 3).

The final model showed that full-term low birthweight babies presented, on average, a postnatal weight 977.4 grams lower than those who were not low birthweight. As age increased (from zero to less than five months), differences in postnatal weight decreased, compared to older babies (between five and six months old). Girls were 426.74 grams lighter than boys, on average.

Table 2. Child characteristics - full-term infants up to six months old $(\mathrm{N}=875)$, Rio de Janeiro city, RJ, Brazil, 2007.

\begin{tabular}{|c|c|}
\hline Infant characteristics & $\begin{array}{r}\text { Participants } \\
\mathbf{n}(\%)\end{array}$ \\
\hline \multicolumn{2}{|l|}{ Gender } \\
\hline Male & $441(50.4)$ \\
\hline Female & $434(49.6)$ \\
\hline \multicolumn{2}{|l|}{ Age (months) } \\
\hline 0 to $<1$ & $99(11.3)$ \\
\hline 1 to $<2$ & $192(21.9)$ \\
\hline 2 to $<3$ & $177(20.2)$ \\
\hline 3 to $<4$ & $169(19.3)$ \\
\hline 4 to $<5$ & $134(15.3)$ \\
\hline 5 to $<6$ & $104(11.9)$ \\
\hline \multicolumn{2}{|l|}{ Birthweight (grams) } \\
\hline$<2,500^{\mathrm{a}}$ & $39(4.5)$ \\
\hline 2,500 to 3,999 & $793(90.6)$ \\
\hline$\geq 4,000$ & $43(4.9)$ \\
\hline \multicolumn{2}{|l|}{ Type of breast feeding } \\
\hline Not applicable $(\mathrm{HIV}+)$ or not stated & $4(0.5)$ \\
\hline Exclusive breast feeding & $493(56.3)$ \\
\hline Predominant breast feeding & $96(11.0)$ \\
\hline Supplemented breast feeding & $196(22.4)$ \\
\hline No longer breast feeds & $86(9.8)$ \\
\hline \multicolumn{2}{|l|}{ In day care centers } \\
\hline Yes & $15(1.7)$ \\
\hline No & $860(98.3)$ \\
\hline \multicolumn{2}{|l|}{ Hospital admission } \\
\hline Yes & $72(8.2)$ \\
\hline No & $800(91.4)$ \\
\hline Unknown & $3(0.4)$ \\
\hline
\end{tabular}


Table 3. Multiple linear regression estimates for postnatal weight of babies in a sample of full-term infants less than six months old $(\mathrm{N}=875)$, Rio de Janeiro city, RJ, Brazil, 2007.

\begin{tabular}{lrr}
\hline $\begin{array}{c}\text { Model } \\
\text { characteristics }\end{array}$ & $\begin{array}{c}\text { Estimate } \\
(\mathbf{g})\end{array}$ & $\begin{array}{c}\text { [95\% Confidence } \\
\text { Interval }]\end{array}$ \\
\hline $\begin{array}{l}\text { Intercept } \\
\text { Low Birthweight }{ }^{\mathrm{a}, \mathrm{b}}\end{array}$ & 7872.17 & {$[7560.68,8183.66]$} \\
$\quad$ Yes & -977.40 & {$[-1215.93,-738.87]$} \\
No & reference & \\
Age of baby & & \\
(months) $^{\mathrm{b}}$ & & \\
0 to $<1$ & -3844.51 & {$[-4211.18,-3477.83]$} \\
1 to $<2$ & -2894.06 & {$[-3189.48,-2598.65]$} \\
2 to $<3$ & -2017.75 & {$[-2363.90,-1671.59]$} \\
3 to $<4$ & -1208.47 & {$[-1507.60,-909.35]$} \\
4 to $<5$ & -766.23 & {$[-1122.74,-409.72]$} \\
5 to $<6$ & reference & \\
Gender & & \\
Female & -426.74 & {$[-540.58,-312.89]$} \\
Male & reference & \\
Live-in partner ${ }^{\mathrm{c}}$ & & \\
Yes & 146.20 & {$[7.04,285.36]$} \\
No & reference & \\
Parity & & \\
Primipara & -204.67 & {$[-318.81,-90.53]$} \\
Multipara & reference & \\
\hline
\end{tabular}

${ }^{a}$ Full-term babies with birthweight less than 2,500 grams were considered babies with intrauterine malnutrition $4 .{ }^{\mathrm{b}} \mathrm{p}<0.001$. ${ }^{c} \mathrm{p}<0.05$.

Among babies whose mothers had live-in partners, the weight was 146 grams higher than for babies whose mothers were single. The offspring of primipara mothers weighed 204.7 grams less than those of multipara mothers (Table 3 ).

\section{Discussion}

Based on these findings, we noted that being born full term and low birthweigth had adverse effects on postnatal weight of babies under six months old in all brackets. Adjusted by marital situation and parity, in addition to child's gender and age, postnatal weight was lower among fullterm babies with low birthweigth than among those weighting 2,500 grams or more.

Eickmann et al. ${ }^{15}$ analyzed the growth of 148 full-term babies up to two years of age in a birth cohort of residents in the Zona da Mata Meridional area of Pernambuco State, Brazil in 1993/1994. An accelerated growth was noted up to six months old, followed by a slowdown up to 12 months, with discrete recovery at two years of age. Although this initial accelerated growth was most marked among low-weight babies (1,500 to 2,499 grams), their weight and length nevertheless remained below those with adequate birthweight (between 3,000 and 3,499 grams) adjusted by social and economic conditions, as well as the occurrence of diarrhea during the first six months of life.

The initial advantage of adequate birthweight in terms of infant growth may be annulled by poor social and economic conditions. The educational level of the mother, which is indirectly related to social and economic status, is a co-variable strongly associated with infant growth, often appearing as a factor independent of income and stepping up the odds of stunted growth, particularly among poorly or uneducated mothers ${ }^{23}$. In this study, variables related directly or indirectly to social and economic conditions were not associated with postnatal weight adjusted by child gender and age, possibly due to the homogeneity of the population studied: users of government-run primary care units. It must also be borne in mind that the entry of variables proximal to the outcome might have minimized the power of association of distal variables such as social and economic conditions, probably through mediation of the final outcome.

Marital status can reflect psycho-social support available to mother and child. Among other factors, the absence of a live-in partner is also related to early weaning and inadequate introduction of food items before the age of six months, possibly affecting infant growth ${ }^{24}$ and less increment of mean weight-for-age in full term children at 12 months age ${ }^{15}$.

In our study, maternal age was not associated with postnatal weight, contradicting studies 
demonstrating that the offspring of teen mothers weigh less than babies of adult women.

Some potential risk factors for infant growth that were considered in our analysis as confounding factors - type of feeding and hospital admission - did not present any association in the regression models controlled by baby age and gender.

Breast feeding is also characterized as influencing infant growth, although studies may present controversial findings. Exclusive breast feeding beyond 2 months of age was related to lower weight gain from 2 to 6 months as well as from 6 to 12 months of age in two Nordic countries ${ }^{25}$. The clinical trial conducted by Kramer and Kaku$\mathrm{ma}^{26}$ reached the conclusion that babies who are solely breastfed may present faster gains in weight and length during the first few months of life, with no deficit at 12 months. In our study, the type of breast feeding adjusted by gender and age was not associated with postnatal weight of the child.

Primiparity is associated with small for gestational age at birth at term ${ }^{27}$, low birthweight and young mothers ${ }^{28}$, low educational levels and exclusive breast feeding weaning ${ }^{29}$. In our study, although controlled for these risk factors, primiparity proved to be associated with lower postnatal weight among full-term low birthweight babies.

It is believed that this study has contributed to the methodology of studies of fetal programming. The intrauterine growth restriction marker most widely used in these studies is low birthweight ${ }^{17,30}$. However, this marker does not exclude preterm births, which is one of the mechanisms leading to low birthweight, increasing the number of false positives and undermining validity. Our study used a more specific but simplified intrauterine growth restriction definition (low birthweight in non preterm infants) and with potential validity problems. In addition to excluding preterm low birthweight babies, full term infants with birthweights greater than 2,500 grams may be small for gestational age and would not be identified (false negatives). However, it is believed that this situation would occur in only a few cases, if it did in fact take place in our study population.

Recent findings present evidence that small for gestational age at term is not a homogeneous group: the determinants of severe small for gestational age (birthweight $<3$ rd for gestational age and sex) reflect pathological determinants of intrauterine growth restriction while those of moderate small for gestational age ( 3 rd to $<10$ th percentile for gestational age and sex) reflect a mixture of physiological and pathological deter- minants ${ }^{27}$. The effects of stratifying small for gestational age on linear growth must be considered in future epidemiological studies.

There is much concern over methodology in fetal programming studies that use weight at different times of life (dependent and independent variables in the same model), as birthweight is part of the subsequent weight (recovery growth, postnatal weight, weight gain). In our study, we decided not to use birthweight as a continuous explanatory variable, as the intention was merely to classify the babies as having been subject to intrauterine growth restriction or not, rather than explaining postnatal weight variations as a function of birthweight variations. Although this simplified definition is also based on birthweight, we believe that this might well have minimized the methodological problem described above.

Due to sectional nature of the data with a single postnatal weight measurement in babies of different ages, it was not possible to analyze growth rates during the first six months of life. Consequently, it was also not possible to investigate catch-up growth as the two Brazilian birth cohort studies in São Luís (MA) and Ribeirão Preto $(\mathrm{SP})^{31}$, and Pelotas (RS) ${ }^{11}$. The first one found association between term low birthweight babies and catch-up growth at the age nine and eleven, and the second identified catch-up growth in first-born babies at age of four.

The sectional nature of the data also caused internal validity problems, such as the survival bias. It is possible that small for gestational age fetuses/newborns after 37 weeks have a higher probability of stillbirth and infant mortality, leading to under-representation of intrauterine growth restriction frequency in the study population, and consequently weakening its association with postnatal weight.

Another internal validity problem that might have occurred is an error in gestational age classification, which is an eligibility criterion for the study. There are no records on how this is measured in SINASC in 2007 (last menstruation date, ultrasound, physical and neurological signs of newborn maturity using the New Ballard score). Although there is a good reability on these data ${ }^{32}$, validity problems can persist when neonatal estimatives are used, leading to bias in the association investigated ${ }^{33}$.

In brief, regarding infant growth, we can conclude that full-term low birthweight infants, particularly those born to primipara single mothers must have their postnatal growth followed more frequently. 


\section{Collaborations}

SGN Gama was responsible for data collection and supervision of the study. JE Arimatea, CMFP Silva, SC Fonseca and PL Kale, participated in the conception of the study and the data analysis. SGN Gama, JE Arimatea, CMFP Silva, SC Fonseca, PL Kale, AJL Costa and EMA Lacerda were involved in writing this paper and approved the final manuscript.

\section{References}

1. De Onis M, Blössner M. The World Health Organization global database on child growth and malnutrition: methodology and applications. Int J Epidemiol 2003; 32(4):518-526.

2. Boguszewski MC, Mericq V, Bergada I, Damiani D, Belgorosky A, Gunczler P, Ortiz T, Llano M, Domené HM, Calzada-León R, Blanco A, Barrientos M, Procel P. Latin American consensus: children born small for gestational age. BMC Pediatrics 2001; 11:66.

3. Lee PA, Chernausek SD, Hokken-Koelega AC, Czernichow P. International Small for Gestational Age Advisory Board. International small for gestational age advisory board consensus development conference statement: management of short children born small for gestational age. Pediatrics 2003; 111(6 Pt 1):12531261.

4. Kiely JL, Brett KM, Yu S, Rowley DL. Low Birthweight and Intrauterine Growth Retardation. In: Wilcox LS, Marks JS, editors. From data to action: CDC's public health surveillance for women, infants, and children. Atlanta: Centers for Disease Control and Prevention; 1994. p. 186-202.

5. Williams RL, Creasy RK, Cunningham GC, Hawes WE, Norris FD, Tashiro M. Fetal growth and perinatal viability in California. Obstet Gynecol 1982; 59(5):624632.

6. Alexander GR, Himes JH, Kaufman RB, Mor J, Kogan M. A United States national reference for fetal growth. Obstet Gynecol 1996; 87(2):163-168.

7. Pedreira CE, Pinto FA, Pereira SP, Costa ES. Birth weight patterns by gestational age in Brazil. An Acad Bras Ciênc 2011; 83(2):619-625.

8. Victora CG, Aquino EM, Leal MC, Monteiro, CA, Barros FC, Szwarcwald CL. Maternal and child health in Brazil: progress and challenges. Lancet 2011; 377(9780):1863-1876.

9. Barros FC, Barros AJ, Villar J, Matijasevich A, Domingues MR, Victora CG. How many low birthweight babies in low- and middle-income countries are preterm? Rev Saude Publica 2011; 45(3):607-616.

10. World Health Organization (WHO). WHO Child growth standards: growth velocity based on weight, length and head circumference: methods and development. Geneva: WHO; 2009.

11. Wells JC, Hallal PC, Reichert FF, Dumith SC, Menezes AM, Victora CG. Associations of birth order with early growth and adolescent height, body composition, and blood pressure: prospective birth cohort from Brazil. Am J Epidemiol 2011; 174(9):1028-1035.

12. Pedraza DF, Rocha ACD, Sousa CPC. Crescimento e deficiências de micronutrientes: perfil das crianças assistidas no núcleo de creches do governo da Paraíba, Brasil. Cien Saude Colet 2013; 18(11):3379-3390.

13. Chrestani MA, Santos IS, Horta BL, Dumith SC, Dode MASO. Associated factors for accelerated growth in childhood: a systematic review. Matern Child Health J 2012; 17(3):512-519.

14. Hokken-Koelega AC, de Ridder MA, Lemmen RJ, Hartog HD, Keizer-Schrama SMPFM, Drop SLS. Children born small for gestational age: do they catch up? Pediatr Res 1995; 38(2):267-271. 
15. Eickmann SH, Lima MC, Motta ME, Romani SAM, Lira PIC. Growth of full term low and adequate birth weight infants during the first two years of life. Rev Saude Publica 2006; 40(6):1073-1081.

16. Ong KK. Size at birth, postnatal growth and risk of obesity. Horm Res 2006; 65(Supl. 3):65-69.

17. Barker DJ. Mothers, babies and health in later life. $2^{\text {nd }} \mathrm{ed}$. London: Churchill Livingstone; 1998.

18. Victora CG, Adair L, Fall C, Hallal PC, Martorell R, Richter L, Sachdev HS; Maternal and Child Undernutrition Study Group. Maternal and child undernutrition: consequences for adult health and human capital. Lancet 2008; 371(9609):340-357.

19. Christian P, Lee SE, Donahue MA, Adair LS, Arifeen SE, Ashorn P, Barros FC, Fall CH, Fawzi WW, Hao W, Hu G, Humphrey JH, Huybregts L, Joglekar CV, Kariuki SK, Kolsteren P, Krishnaveni GV, Liu E, Martorell R, Osrin D, Persson LA, Ramakrishnan U, Richter L, Roberfroid D, Sania A, Ter Kuile FO, Tielsch J, Victora CG, Yajnik CS, Yan H, Zeng L, Black RE. Risk of childhood undernutrition related to small-for-gestational age and preterm birth in low and middle-income countries. Int J Epidemiol 2013; 42(5):1340-1355.

20. Niquini RP, Bittencourt SA, Lacerda EMA, Leal, MC. Fatores associados à introdução precoce de leite artificial, Município do Rio de Janeiro, 2007. Rev Bras Epidemiol 2009; 12(3):446-457.

21. Leal MC, Gama SG, Ratto KM, Cunha CB. Use of the modified kotelchuck index in the evaluation of prenatal care and its relationship to maternal characteristics and birth weight in Rio de Janeiro, Brazil. Cad Saude Publica 2004; 20(Supl. 1):S67-72.

22. World Health Organization (WHO). Indicators for assessing infant and young child feeding practices. Part I: Definitions conclusions of consensus meeting held 6-8 november 2007. Geneva: WHO; 2007.

23. Romani SAM, Lira PIC. Determinant factors of infant growth. Rev Bras Saude Mater Infant 2004; 4(1):15-23.

24. Kimani-Murage EW, Madise NJ, Fotso JC, Kybutungi C, Mutua MK, Gitau TM, Yatich N. Patterns and determinants of breastfeeding and complementary feeding practices in urban informal settlements, Nairobi Kenya. BMC Public Health 2011; 11:396.

25. Gunnarsdottir I, Schack-Nielsen L, Michaelsen KF, Sørensena TIA, Thorsdotti I. Infant weight gain, duration of exclusive breast feeding and childhood BMI two similar follow-up cohorts. Public Health Nutr 2010; 13(2):201-207.
26. Kramer MS, Kakuma R. Optimal duration of exclusive breastfeeding. Cochrane Database Syst Rev 2012; 8:CD003517.

27. Campbell MK, Cartier S, Xie B, Kouniakis G, Huang W, Han V. Determinants of small for gestational age birth at term. Paediatr Perinat Epidemiol 2012; 26(6):525533.

28. Al-Farsi YM, Brooks DR, Werler MM, Cabral HJ, Al-Shafaee MA, Wallenburg HC. Effect of high parity on occurrence of some fetal growth indices: a cohort study. Int J Womens Health 2012; 4:289-293.

29. Bernardi JL, Jordão RE, Barros Filho AA. Cross-sectional study on the weight and length of infants in the interior of the State of São Paulo, Brazil: associations with sociodemographic variables and breastfeeding. Sao Paulo Med J 2009; 127(4):198-205.

30. Rich-Edwards J. Epidemiology of the fetal origins of adult disease: cohort studies of birthweight and cardiovascular disease. In: Langley-Evans SC, editor. Perinatal Epidemiology for Public Health Practice. Wallingford: CABI Publishing; 2009. p. 87-104.

31. Batista RFL, Silva AAM, Barbieri MA, Simões VMF Bettiol H. Factors Associated with Height Catch-Up and Catch-Down Growth Among Schoolchildren. PLoS ONE 2012; 7:e32903.

32. Theme Filha MM, Gama SGN, Cunha CB, Leal MC Confiabilidade do Sistema de Informações sobre $\mathrm{Na}$ scidos Vivos Hospitalares no Município do Rio de Janeiro, 1999-2001. Cad Saude Publica 2004; 20(Supl. 1):S83-S91.

33. Moraes CL, Reichenheim ME. Validity of neonatal clinical assessment for estimation of gestational age: comparison of New Ballard score with date of last menstrual period and ultrasonography. Cad Saude Publica 2000; 16(1):83-94.

Article submitted 06/02/2014

Approved 09/13/2014

Final version submitted 09/15/2014 